\title{
Microscopic differential cell counts in milk for the evaluation of inflammatory reactions in clinically healthy and subclinically infected bovine mammary glands
}

\author{
Daniel Schwarz ${ }^{1}$, Ulrike S Diesterbeck ${ }^{1}$, Sven König ${ }^{2}$, Kerstin Brügemann², Karen Schlez ${ }^{3}$, \\ Michael Zschöck ${ }^{3}$, Wilfried Wolter ${ }^{4}$ and Claus-Peter Czerny ${ }^{1 *}$ \\ ${ }^{1}$ Department of Animal Sciences, Institute of Veterinary Medicine, Division of Microbiology and Animal Hygiene, Faculty of Agricultural \\ Sciences, Georg-August-University Göttingen, Burckhardtweg 2, D-37077 Göttingen, Germany \\ ${ }^{2}$ Department of Animal Breeding, University of Kassel, Nordbahnhofstraße 1a, D-37213 Witzenhausen, Germany \\ ${ }^{3}$ Landesbetrieb Hessisches Landeslabor, Schubertstraße 60, D-35392 Giessen, Germany \\ ${ }^{4}$ Regierungspräsidium Giessen, Milk Control, Schanzenfeldstraße 8, D-35578 Wetzlar, Germany
}

Received 7 March 2011; accepted for publication 12 July 2011; first published online 16 August 2011

\begin{abstract}
Somatic cell count (SCC) is generally regarded as an indicator of udder health. A cut-off value of $100 \times 10^{3}$ cells $/ \mathrm{ml}$ is currently used in Germany to differentiate between normal and abnormal secretion of quarters. In addition to SCC, differential cell counts (DCC) can be applied for a more detailed analysis of the udder health status. The aim of this study was to differentiate somatic cells in foremilk samples of udder quarters classified as normal secreting by SCC $<100 \times 10^{3}$ cells $/ \mathrm{ml}$. Twenty cows were selected and 72 normal secreting udder quarters were compared with a control group of six diseased quarters (SCC $>100 \times 10^{3}$ cells $/ \mathrm{ml}$ ). In two severely diseased quarters of the control group (SCC of $967 \times 10^{3}$ cells $/ \mathrm{ml}$ and $1824 \times 10^{3}$ cell $\mathrm{s} / \mathrm{ml}$ ) Escherichia coli and Staphylococcus aureus were detected. DCC patterns of milk samples $(n=25)$ with very low SCC values of $\leqslant 6 \cdot 25 \times 10^{3}$ cells $/ \mathrm{ml}$ revealed high lymphocyte proportions of up to $92 \%$. Milk cell populations in samples $(n=41)$ with SCC values of $(>6.25$ to $\leqslant 25) \times 10^{3}$ cells $/ \mathrm{ml}$ were also dominated by lymphocytes (mean value $47 \%)$, whereas DCC patterns of milk from udder quarters $(n=6)$ with SCC values $(>25$ to $\leqslant 100)$ $\times 10^{3}$ cells $/ \mathrm{ml}$ changed. While in samples $(n=3)$ with SCC values of $(27-33) \times 10^{3}$ cells $/ \mathrm{ml}$ macrophages were predominant (35-40\%), three milk samples with $(43-45) \times 10^{3}$ cells/ml indicated already inflammatory reactions based on the predominance of polymorphonuclear leucocytes (PMN) (54-63\%). In milk samples of diseased quarters PMN were categorically found as dominant cell population with proportions of $\geqslant 65 \%$. Macrophages were the second predominant cell population in almost all samples tested in relationship to lymphocytes and PMN. To our knowledge, this is the first study evaluating cell populations in low SCC milk in detail. Udder quarters classified as normal secreting by SCC $<100 \times 10^{3}$ cells $/ \mathrm{ml}$ revealed already inflammatory processes based on DCC.
\end{abstract}

Keywords: Differential cell counts, subclinical mastitis, udder health, low somatic cell counts.

For mastitis diagnosis, traditional and well-established tests including somatic cell count (SCC) and microbial culturebased methods are standard (Viguier et al. 2009). According to current definitions of udder health in Germany, SCC $\leqslant 100 \times 10^{3}$ cells $/ \mathrm{ml}$ in quarter foremilk samples are in the physiological range (DVG, 2002). It is well known that the

*For correspondence; e-mail: cczerny@gwdg.de crossover of normal cellular defence in the mammary gland into an inflammatory reaction starts at a level of $>100 \times 10^{3}$ cells/ml (Harmon, 1994; DVG, 2002). However, SCC varies with the status of lactation, age, stress of the animals, time and frequency of milking, season, and status of udder infection (Dohoo \& Meek, 1982; Harmon, 1994). SCC is a robust quantitative estimate, but it does not divide the cells present in milk into different cell types (Kehrli \& Shuster, 1994; Rivas et al. 2001).

In the mammary gland, number and distribution of leucocytes are important for the success of udder 
defences against invading pathogens (Leitner et al. 2003). Lymphocytes, macrophages, and polymorphonuclear leucocytes (PMN) play an important role in immune reactions within the mammary gland (Paape et al. 1979; Sordillo \& Nickerson, 1988). Induction and suppression of immune responses are regulated by lymphocytes (Nickerson, 1989). They recognize antigens through membrane receptors specific for invading pathogens (Sordillo et al. 1997). Macrophages are active phagocytic cells in the mammary gland and capable of ingesting bacteria, cellular debris and accumulated milk components (Sordillo \& Nickerson, 1988). Milk or tissue macrophages recognize the invading pathogens and initiate an immune response by the release of chemo-attractants inducing the rapid recruitment of PMN into the mammary gland (Paape et al. 2002; Oviedo-Boyso et al. 2007). The main task of PMN is the defence of invading bacteria at the beginning of an acute inflammatory process (Paape et al. 1979; Oviedo-Boyso et al. 2007). Not only does the number of PMN increase enormously, but also their level of defence activity (Targowski, 1983; Paape et al. 2003).

The distribution of leucocyte types varies in normal milk without any symptoms of mastitis. Some previous studies found lymphocyte proportions between 14 and $80 \%$, macrophage proportions between 12 and $46 \%$, and those of PMN between 6 and 50\% (Rivas et al. 2001; Merle et al. 2007; Koess \& Hamann, 2008). In mastitis milk, PMN proportions of up to $95 \%$ have been reported (Paape et al. 1979; Kehrli \& Shuster, 1994). During various phases of inflammation SCC differs in total numbers, whereas differential cell count (DCC) varies in composition of the cell populations involved (Nickerson, 1989). Therefore, in addition to SCC, determination of different types of immune cells present in milk is beneficial for describing udder health status (Pillai et al. 2001; Rivas et al. 2001). So far, however, there is little knowledge on DCC and the qualitative role of milk leucocytes in healthy udders because DCC in low-SCC milk is difficult to perform (Dosogne et al. 2003).

Data from a previous study (Schwarz et al. 2010) indicated a high standard of udder health in a representative part of the dairy cow population in the German federal state Hesse and confirmed the threshold of $100 \times 10^{3} \mathrm{cells} / \mathrm{ml}$ differentiating between normal and abnormal secretion of quarters. However, unexpectedly high numbers of mastitis pathogens in the SCC range $\leqslant 100 \times 10^{3}$ cells $/ \mathrm{ml}$ were found. They could already be detected at a threshold of $1 \times 10^{3}$ cell $\mathrm{s} / \mathrm{ml}$. Based on these data we suspected inflammatory processes even within the SCC range of mammary glands classified as healthy according to current definitions. Therefore, the objective of this study was the detailed evaluation of health status in udder quarters with SCC clearly $<100 \times 10^{3}$ cells $/ \mathrm{ml}$ based on a statistical analysis of DCC. Leucocytes were isolated from quarter foremilk samples and differentiated into lymphocytes, macrophages, and PMN using microscopy.

\section{Materials and Methods}

\section{Animals and farms}

Twenty dairy cows in good condition and without previous history of mastitis were selected from four German dairy farms (A-D) for a detailed analysis of their udder health status based on DCC in quarter foremilk samples. The animals, Holstein-Frisian cows $(n=18)$ and German Simmental cows $(n=2)$, were in different lactations (1-6) and stages of the lactation. Six cows were in their first, seven in their second, three in their third, one in her fourth, two in their fifth and one in her sixth lactation. Seven animals were in an early stage of lactation (28-86 d), eight were in mid lactation (107-177 d) and five in a late stage of lactation (212-289 d). Foremilk samples from 72 udder quarters of the 20 cows classified as normal secreting (SCC $\leqslant 100 \times 10^{3}$ cells $/ \mathrm{ml}$ and no pathogen) were selected for DCC analysis. A further 6 quarter foremilk samples with SCC of $(100-1824) \times 10^{3}$ cells $/ \mathrm{ml}$ were chosen from 6 cows as control group. Clinical mastitis symptoms such as flecks in milk, swelling or redness of the udder quarters could only be observed in quarters with SCC $>100 \times 10^{3}$ cells $/ \mathrm{ml}$.

In Farms A-D, 52-109 dairy cows were housed in pen barns and milked twice a day in milking parlours. Milking operations were similar in all farms. After forestripping into a foremilk cup, the milkers used damp cotton tissues for udder cleaning. Teats were dipped after milking with iodine solution. Feeding comprised a total mixed ration consisting of grass and maize silage, rape grist and cereals. Water was available ad libitum. Farm A produced high quality milk, while farms B-D were conventional milk producers. The average herd annual milk yields of the four farms ranged between 6500 and $9900 \mathrm{~kg}$.

\section{Milk sampling}

Quarter foremilk samples were obtained according to DVG (2000) standards. Before milking, teat ends were scrubbed with $70 \%$ ethanol and the first two squirts of milk were discarded. Ten millilitres of milk per udder quarter was collected aseptically in a sterile 14 -ml plastic sample tube (Greiner Bio-one, Frickenhausen, Germany). Four millilitres was used for SCC and bacteriological examinations, the remaining $6 \mathrm{ml}$ was subjected to DCC analysis.

Quarter foremilk samples were taken on farms B-D during morning milking. Further processing occurred within $4 \mathrm{~h}$. Samples on farm A were collected during evening milking and analysed within $15 \mathrm{~h}$.

\section{Somatic cell counts and bacteriological examinations}

SCC was determined using a Fossomatic 5000 (Foss Electric, Hillerød, Denmark). Cytobacteriological analysis of all quarter foremilk samples was performed according to IDF (1981) standards. Promptly after collecting the quarter foremilk samples and cooled-transportation to the laboratory, $10 \mu \mathrm{l}$ of milk was streaked onto a quadrant of a $7 \%$ 
bovine blood agar plate containing $0.05 \%$ aesculin (Merck, Darmstadt, Germany), incubated for $48 \mathrm{~h}$ at $37^{\circ} \mathrm{C}$, and examined for bacterial growth.

\section{Differential cell counts}

Six millilitres of each quarter foremilk sample was transferred into a sterile $14-\mathrm{ml}$ plastic tube. Milk samples were then centrifuged at $200 \mathrm{~g}$ at $4{ }^{\circ} \mathrm{C}$ for $15 \mathrm{~min}$. Cream layers and supernatants were discarded and cells were washed once in PBS by centrifugation at $200 \mathrm{~g}$ at $4{ }^{\circ} \mathrm{C}$ for $15 \mathrm{~min}$. Cell pellets were finally resuspended in $20 \mu \mathrm{l}$ PBS. To obtain as many cells as possible for DCC analysis on the microscope slide, the whole sediment of the tube was spread over an area of $2 \mathrm{~cm}^{2}$. Cell staining was performed according to the method of Pappenheim (1912).

Evaluation of the slides followed using light microscopy and oil immersion (100-fold magnification). One-hundred cells of each slide were counted meander-shaped and differentiated into lymphocytes, macrophages and PMN. Cell identification occurred according to standard methods (Coles, 1974; Lee et al. 1980). Lymphocytes were identified based on their circular form (5-10 $\mu \mathrm{m})$ and the typical shape of the nucleus that almost fills the cell leaving a very thin rim of cytoplasm. Cells of 8-30 $\mu \mathrm{m}$ in size containing a little nucleus and pale staining were considered as macrophages. The group of PMN was characterized as cells of 10-14 $\mu \mathrm{m}$ in size and segmented nuclei. They were intensely coloured and contained granula in the cytoplasm.

\section{Statistical analyses}

Associations between values for individual cell populations and values for SCC were analysed by applying linear mixed models as implemented in the SAS program (version 9.1, SAS Institute, Cary NC, USA). The statistical model included fixed and random effects as well as a regression on SCC up to the third polynomial degree, in order to fit regression curves. The non-significant regression coefficients of different polynomial structures were removed from the model by using $F$-statistics sum of square type I tests at $P<0 \cdot 05$ instead of likelihood ratio tests. Based on type I sums of squares at $P<0 \cdot 05$, a sequential analysis approach is appropriate for polynomial formulated models (Littell et al. 1998). The applied statistical model [1] was defined as follows:

$$
\begin{aligned}
y_{i j k l}= & \mu+\text { herd }_{i}+\text { parity }_{j}+\text { DIM }_{k}+\text { Cow }_{1}+\alpha_{1} \text { SCC }_{i j k l} \\
& +\alpha_{2} \text { SCC }_{i j \mathrm{jl}}^{2}+\alpha_{3} \text { SCC }_{i \mathrm{jkl}}^{3}+\mathrm{e}_{\mathrm{ijkl}}
\end{aligned}
$$

where:

$y_{i j k l}=\quad$ observation for the individual cell population (lymphocytes, macrophages, PMN) of the individual udder quarter of cow 1

$\mu=\quad$ overall mean effect

herd $_{i}=$ fixed effect of the $\mathrm{i}$-th herd of cow 1

parity $_{j}=$ fixed effect of the $\mathrm{j}$-th lactation number of cow $\mathrm{I}[1$, $2, \geq 3]$
$D_{1 M}=$ fixed effect of the k-th stage of lactation of cow I [early, 28-86 d; mid, 107-177 d; late, $212-289 \mathrm{~d}]$

$\mathrm{Cow}_{\mathrm{l}}=\quad$ random effect of cow $\mathrm{I}$

$\mathrm{SCC}_{\mathrm{ijkl}}=$ value for SCC of the individual udder quarter of cow I

$\alpha_{1}, \alpha_{2}$, linear, quadratic, and cubic regression on SCC

$\alpha_{3}=$

$\mathrm{e}_{\mathrm{ijk} k \mathrm{l}}=\quad$ random residual effect

For verification of results of model [1], and to test DCC data especially for differences in the SCC range $\leqslant 100 \times 10^{3}$ cells/ $\mathrm{ml}$, analysis of variance was additionally done by including a fixed effect of the SCC group and removing the SCC covariates from the statistical model. Therefore, all 78 udder quarters were classified into SCC groups I-IV as defined in a previous study (Schwarz et al. 2010). Group IV represented the control quarters. Twenty-five (31\%) of the 78 samples analysed belonged to group I according to their SCC values of $\leqslant 6 \cdot 25 \times 10^{3}$ cells $/ \mathrm{ml}$. Forty-one samples $(53 \%)$ showed SCC values of $(>6 \cdot 25$ to $\leqslant 25) \times 10^{3}$ cells $/ \mathrm{ml}$ (group II). Six samples $(8 \%)$ with SCC of $(>25$ to $\leqslant 100) \times 10^{3}$ cells $/ \mathrm{ml}$ were categorized into group III. A further six samples ( $8 \%)$ with SCC $>100 \times 10^{3}$ cells $/ \mathrm{ml}$ were sorted into group IV. The applied statistical model [2] was defined as follows:

$$
\begin{aligned}
y_{i j k l m}= & \mu+\text { herd }_{i}+\text { parity }_{j}+\text { DIM }_{k}+\text { cow }_{l}+\text { group }_{m} \\
& +e_{i j k l m}
\end{aligned}
$$

where:

$y_{\mathrm{ijk} k m}=$ observation for the individual cell population (lymphocytes, macrophages, PMN) of the individual udder quarter of cow 1

$\mu=\quad$ overall mean effect

herd $_{i}=$ fixed effect of the $i$-th herd of cow $I$

parity $_{j}=$ fixed effect of the $j$-th lactation number of cow I $[1,2, \geqslant 3]$

$D I M_{k}=$ fixed effect of the k-th stage of lactation of cow I [early, 28-86 d; mid, 107-177 d; late, 212$289 \mathrm{~d}]$

$\mathrm{cow}_{1}=$ random effect of cow $\mathrm{I}$

group $_{\mathrm{m}}=$ fixed effect of the $\mathrm{m}$-th SCC-group $[\mathrm{l}, \leqslant 6 \cdot 25 \times$ $10^{3}$ cells $/ \mathrm{ml} ; \mathrm{II},(>6 \cdot 25$ to $\leqslant 25) \times 10^{3}$ cell $/ \mathrm{ml}$; III, $(>25$ to $\leqslant 100) \times 10^{3}$ cells $/ \mathrm{ml} ; \mathrm{IV},>100 \times 10^{3}$ cells/ $\mathrm{ml}]$

$\mathrm{e}_{\mathrm{ij} k \mathrm{klm}}=$ random residual effect

\section{Results}

\section{Somatic cell counts and bacteriological status of quarter foremilk samples}

The 78 udder quarters selected showed a geometric mean value for SCC of $11.78 \times 10^{3}$ cells $/ \mathrm{ml}$ and a median of $10 \times 10^{3} \mathrm{celll} / \mathrm{sl}$. The quarter with the lowest SCC contained $1 \times 10^{3}$ cells $/ \mathrm{ml}$, the quarter with the highest SCC contained $1824 \times 10^{3}$ cells $/ \mathrm{ml}$. Udder pathogenic microorganisms were identified in only two of the 78 quarter foremilk samples. In two of the six control quarters (SCC of 
Table 1. General overview of differential cell counts (DCC) of 78 quarter foremilk samples analysed by microscopy

\begin{tabular}{lllc} 
& \multicolumn{3}{c}{ DCC in\% } \\
\cline { 2 - 4 } & Lymphocytes & Macrophages & PMNt \\
Mean & $44 \cdot 56$ & $34 \cdot 85$ & $19 \cdot 94$ \\
SD & $21 \cdot 63$ & $15 \cdot 20$ & $21 \cdot 40$ \\
Minimum & 2 & 8 & 0 \\
Maximum & 92 & 68 & 88
\end{tabular}

†Polymorphonuclear leucocytes

Table 2. Results of variance analysis (model [1]) for the percentage of the individual cell populations in 78 quarter foremilk samples analysed by microscopyt

Effect

\begin{tabular}{|c|c|c|c|c|c|}
\hline $\begin{array}{l}\text { Cell } \\
\text { population }\end{array}$ & SCC & $\begin{array}{l}\text { Quarter } \\
\text { position }\end{array}$ & $\begin{array}{l}\text { Lactation } \\
\text { number }\end{array}$ & $\begin{array}{l}\text { Days } \\
\text { in milk }\end{array}$ & Farm \\
\hline Lymphocytes & $0 \cdot 0001$ & $0 \cdot 41$ & $0 \cdot 21$ & $0 \cdot 14$ & 0.05 \\
\hline Macrophages & $0 \cdot 01$ & $0 \cdot 68$ & $0 \cdot 33$ & 0.07 & 0.05 \\
\hline PMN\# & $0 \cdot 0001$ & $0 \cdot 13$ & $0 \cdot 29$ & 0.77 & $0 \cdot 13$ \\
\hline
\end{tabular}

†Factors analysed were somatic cell count (SCC), quarter positions (front right, rear right, front left, and rear left), lactation number $(1,2, \geqslant 3)$, days in milk (28-86 d, 107-177 d, 212-289 d), and farm (A-D)

‡Polymorphonuclear leucocytes

$967 \times 10^{3}$ cells $/ \mathrm{ml}$ and $1824 \times 10^{3}$ cells $/ \mathrm{ml}$ ) Escherichia coli and Staphylococcus aureus were detected.

\section{Differential cell counts of quarter foremilk samples depending on somatic cell counts}

For a more detailed evaluation of the udder health status 100 cells per quarter foremilk sample were differentiated into lymphocytes, macrophages, and PMN. In view of DCC $(n=78)$ the proportions of lymphocytes lay between 2 and $92 \%$ with a mean of $44.56 \%$ and SD of $21.63 \%$ (Table 1 ). Proportions of macrophages ranged between 8 and $68 \%$ with a mean of $34 \cdot 85 \%$ and SD of $15 \cdot 20 \%$. PMN proportions varied between 0 and $88 \%$ with a mean of $19.94 \%$ and SD of $21 \cdot 40 \%$

Because of the wide variations found within the cell populations, particularly in case of lymphocytes and PMN, DCC data were tested for correlation with SCC using the statistical model [1].

Lymphocytes decreased continuously from $92 \%$ at SCC of $1 \times 10^{3}$ cells $/ \mathrm{ml}$ to only $5 \%$ at an SCC of $1824 \times 10^{3}$ cells $/ \mathrm{ml}$ (Fig. 1A). The statistical analysis (model [1]) indicated a significant $(P<0 \cdot 001)$ negative correlation between percentages of lymphocytes and SCC (Table 2).

Percentages of PMN (Fig. 1B) and lymphocytes (Fig. 1A) emerged in contrary directions at rising SCC. PMN increased constantly from $0 \%$ at SCC of $1 \times 10^{3}$ cells $/ \mathrm{ml}$ to a maximum of $88 \%$ at $139 \times 10^{3}$ cells $/ \mathrm{ml}$. At SCC of $1824 \times 10^{3}$ cells $/ \mathrm{ml}$
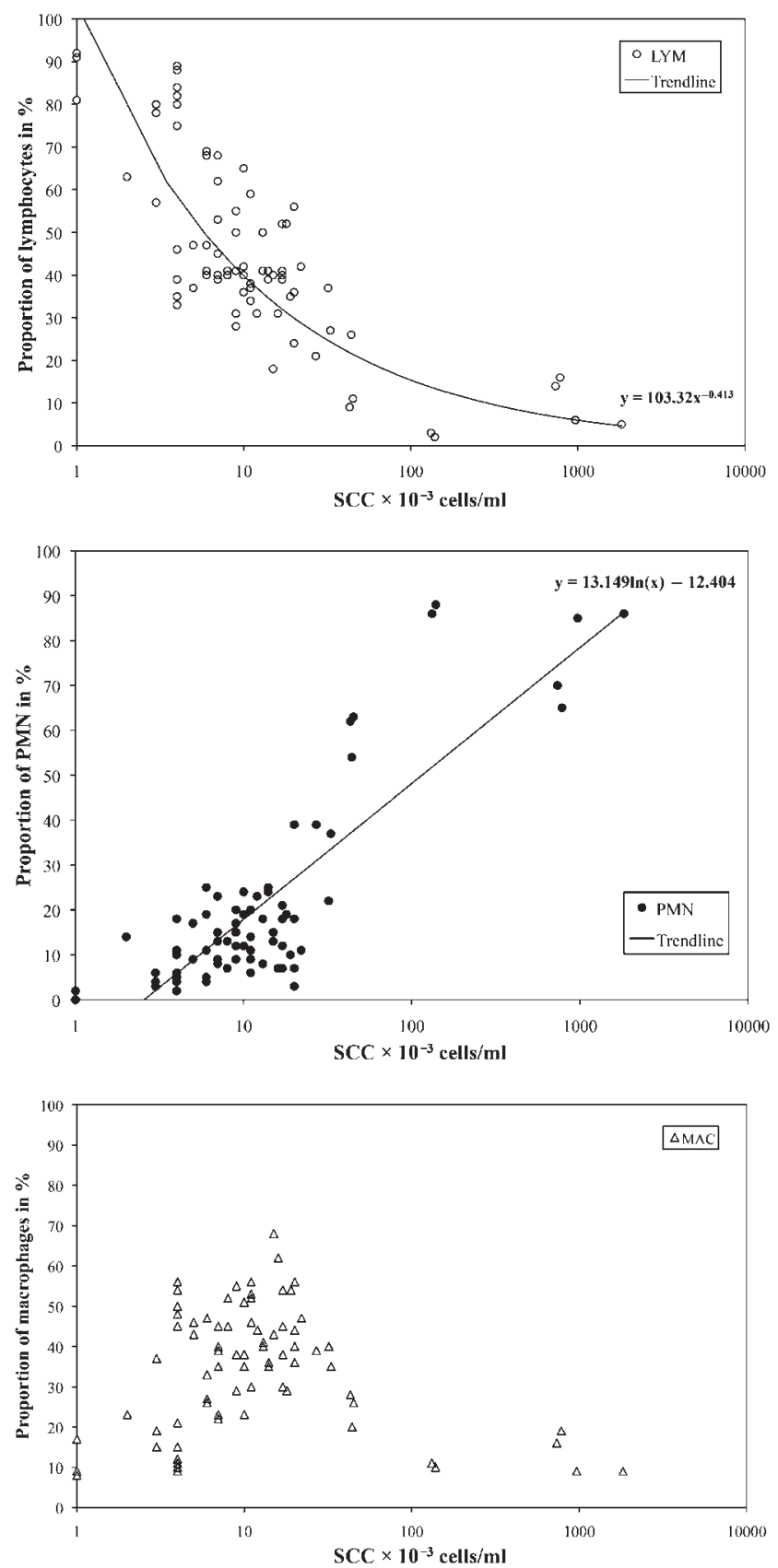

Fig. 1. A-C. Differential cell counts (DCC) depending on somatic cell counts (SCC): A, Proportions of lymphocytes ( $\bigcirc$ LYM) pictured in combination with a calculated potential trendline; B, Proportions of polymorphonuclear leucocytes $(\bullet \mathrm{PMN})$ pictured in combination with a calculated logarithmic trendline. C, Proportions of macrophages ( $\triangle \mathrm{MAC}$ ); each symbol represents the result of one udder quarter analysed, but overlapping is possible.

the proportion of PMN was $86 \%$. Interestingly, PMN was already the predominant cell population at a SCC level of $43 \times 10^{3}$ cells $/ \mathrm{ml}$ with a proportion of $62 \%$. This event was observed in three udder quarters [SCC $(43-45) \times 10^{3}$ cells/ $\mathrm{ml}$ of three different cows housed in two different farms. Statistical analysis (model [1]) indicated a significant 


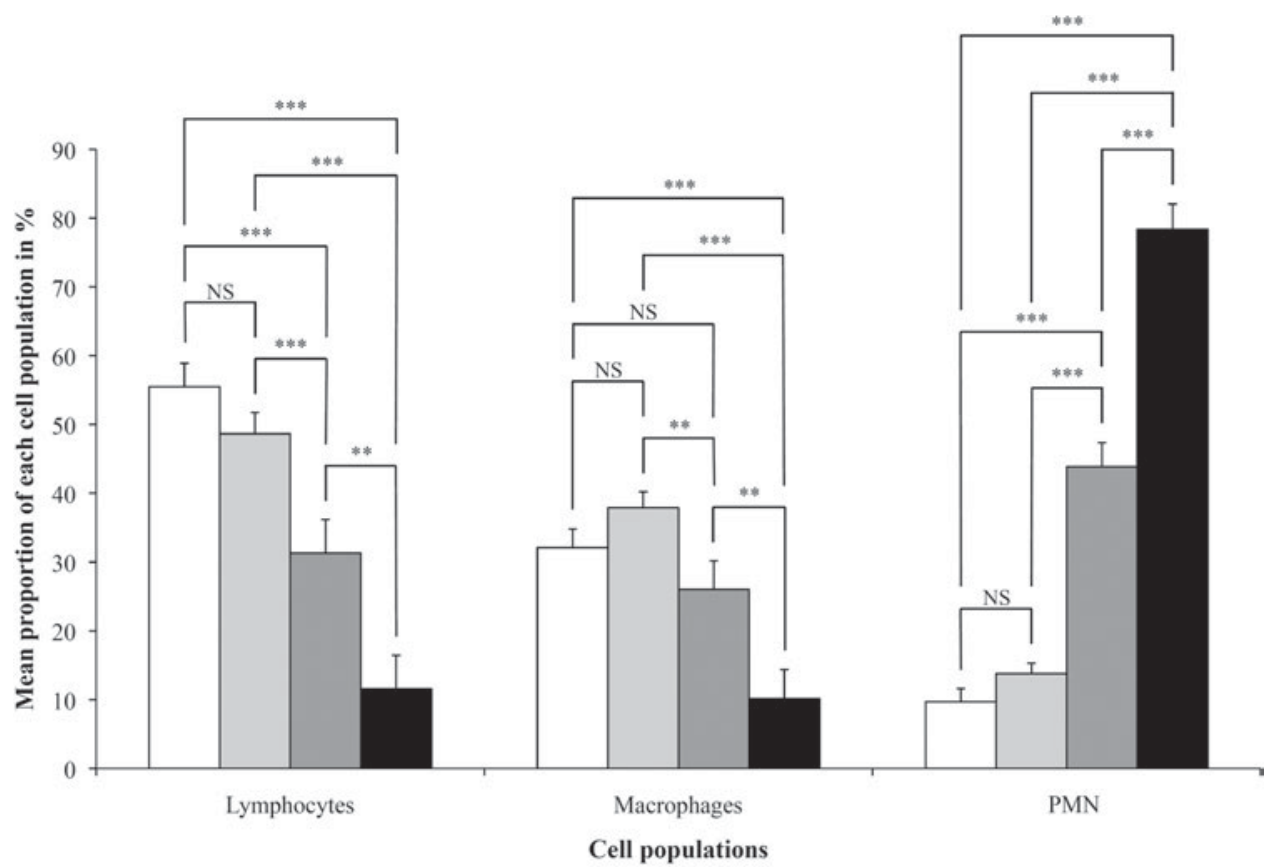

Fig. 2. Comparison of differential cell counts (DCC) within the somatic cell count (SCC) range of healthy mammary glands $\left(\leqslant 100 \times 10^{3}\right.$ cells/ $\mathrm{ml}$ ) using statistical model [2]. All 78 udder quarters analysed were classified into SCC groups I-IV (group I, empty bars, SCC $\leqslant 6 \cdot 25 \times$ $10^{3}$ cells $/ \mathrm{ml}, n=25$; group II, light grey bars, SCC $(>6 \cdot 25$ to $\leqslant 25) \times 10^{3}$ cells $/ \mathrm{ml}, n=41$; group III, dark grey bars, SCC (>25 to $\leqslant 100$ ) $\times 10^{3}$ cells $/ \mathrm{ml}, n=6$; group IV, black bars, SCC $>100 \times 10^{3}$ cells $/ \mathrm{ml}, n=6$ ). Group IV represents the control quarters. Data are expressed as mean \pm SEM for percentages of the individual cell populations in the four SCC groups defined. Significance level: ${ }^{* * *} P<0 \cdot 001 ; * * P<0 \cdot 01$; $* P<0 \cdot 05 ; \mathrm{NS}$, not significant. Abbrevation: PMN, polymorphonuclear leucocytes.

$(P<0 \cdot 001)$ positive correlation between percentage of PMN and SCC (Table 2).

Within the SCC range of $(3-100) \times 10^{3}$ cells $/ \mathrm{ml}$ macrophage proportions lay between $8 \%$ and $68 \%$ (Fig. 1C). At SCC $<3 \times 10^{3}$ cells $/ \mathrm{ml}$ and in samples with $>100 \times 10^{3}$ cells/ $\mathrm{ml}$ proportions of macrophages were $<30 \%$. Statistical analysis (model [1]) revealed a significant $(P<0 \cdot 01)$ negative correlation between macrophage percentage and SCC (Table 2). In addition, the position of the udder quarter, the lactation number and the stage of lactation had no significant impact on the individual cell populations (Table 2). However, percentages of lymphocytes and macrophages were significantly influenced by the farm (Table 2).

Statistical analysis (model [1]) revealed a significant negative correlation between the percentages of lymphocytes and SCC, a significant negative correlation between macrophages and SCC, as well as a significant positive correlation between $\mathrm{PMN}$ and SCC. To test DCC data especially for differences in the SCC range $\leqslant 100 \times 10^{3}$ cells/ $\mathrm{ml}$, a second statistical analysis (model [2]) was performed (Fig. 2).

Lymphocytes indicated significantly $(P<0 \cdot 01)$ higher mean percentages in groups I-III (31.31-55.49\%) than in group IV $(11 \cdot 56 \%)$. Interestingly, mean percentages in groups I and II were significantly $(P<0 \cdot 001)$ higher than those in group III.

Mean percentages of macrophages indicated significant $(P<0 \cdot 01)$ differences between groups I-III $(26 \cdot 02-37 \cdot 88 \%)$ and group IV $(10 \cdot 14 \%)$. In addition, mean percentages were significantly $(P<0 \cdot 01)$ lower in group III than those in group II.

Mean percentages of $\mathrm{PMN}$ differed significantly $(P<0 \cdot 001)$ between groups I-III $(9 \cdot 69-43 \cdot 87 \%)$ and group IV $(78 \cdot 37 \%)$. In addition, mean percentages of PMN were significantly $(P<0 \cdot 001)$ lower in groups I and II than those in group III.

\section{Discussion}

Together with SCC, determination of DCC in milk is an important tool characterizing udder health (Pillai et al. 2001). There are clear SCC cut-offs to differentiate between normal and abnormal secretion of quarters. But even in healthy udders, inflammations can be suspected under special circumstances (Schwarz et al. 2010). The immunological status of mammary glands classified by DCC is poorly investigated. Reviewing the literature Medzhitov (2007) reported that there might be a lack of knowledge on host defence in asymptomatic infections because almost all studies performed so far concentrated on symptomatic infections. In the present study, we differentiated leucocytes purified from quarter foremilk samples to improve knowledge of the immunological status of clinically healthy and subclinically infected bovine mammary glands. While SCC of $>100 \times 10^{3}$ cells $/ \mathrm{ml}$ is normally related to inflammatory 
processes inside the mammary gland, a SCC range of $\leqslant 100 \times 10^{3}$ cells $/ \mathrm{ml}$ is in a physiological band (Harmon, 1994; DVG, 2002) but can also be related to latent mastitis in the presence of pathogens (Schwarz et al. 2010). Here, we predominantly analysed milk samples with SCC $<50 \times 10^{3}$ cells $/ \mathrm{ml}$ to have a high informative value about DCC in low-SCC milk. Our control group (SCC $>100 \times 10^{3}$ cells $/ \mathrm{ml}$ ) included only six quarters. However, the SCC range $>100 \times 10^{3}$ cells $/ \mathrm{ml}$ has been studied extensively before and $\mathrm{PMN}$ has been reported generally to be the dominant cell population in mastitic milk (e.g. Leitner et al. 2000; Merle et al. 2005; Koess \& Hamann, 2008).

It is known that the milk fraction collected has an impact on both SCC and DCC (Sarikaya et al. 2005; Sarikaya \& Bruckmaier, 2006; Olde Riekerink et al. 2007). SCC values in foremilk samples of quarters with a total quarter milk SCC $>100 \times 10^{3}$ cells $/ \mathrm{ml}$ were significantly higher than in cisternal milk (Sarikaya \& Bruckmaier, 2006). In samples with SCC $<100 \times 10^{3}$ cells $/ \mathrm{ml}$ differences of SCC between foremilk and cisternal milk were only minor. While no changes of DCC during milking could be observed in milk with SCC $<200 \times 10^{3}$ cells $/ \mathrm{ml}$, proportions of PMN were higher and proportions of macrophages were lower in milk (SCC $>200 \times 10^{3}$ cells $/ \mathrm{ml}$ ) collected post milking compared with milk collected premilking or during the milking process (Olde Riekerink et al. 2007). Sarikaya et al. (2005) also reported that the proportion of macrophages decreased while that of PMN increased during milking. Since we concentrated predominantly on the analysis of low-SCC milk, we presume that the foremilk samples taken in our study are representative for the analysis of the udder health status.

Our results indicate that lymphocytes were the predominant cell population in healthy mammary glands. Milk samples with an extremely low SCC value of $\leqslant 6 \cdot 25 \times$ $10^{3} \mathrm{cells} / \mathrm{ml}$ revealed high lymphocyte proportions of up to $92 \%$ (mean value: $55 \%$ ). In a SCC range of ( $>6.25$ to $\leqslant 25) \times 10^{3}$ cells $/ \mathrm{ml}$ a high mean proportion of lymphocytes $(49 \%)$ was determined too. Information on DCC in milk samples with such low SCC from other field studies is rare. Only Koess \& Hamann (2008) reported a mean value of $25 \%$ for the proportion of lymphocytes in the SCC range of $(0-50) \times 10^{3}$ cells $/ \mathrm{ml}$. Merle et al. (2007) measured a mean proportion of $25 \%$ of lymphocytes in milk samples with SCC $<100 \times 10^{3}$ cells $/ \mathrm{ml}$. In an experimental study (Rivas et al. 2001) lymphocyte proportions between 54 and $80 \%$ were measured pre-inoculation in udder quarters with SCC $<200 \times 10^{3}$ cells $/ \mathrm{ml}$. Data from our study showed higher proportions of lymphocytes in milk with SCC $<100 \times 10^{3}$ cells/ml than reported before. This difference resulted from the analysis of milk with very low SCC, because lymphocytes were the dominant cell population in these samples. The proportions of $2-16 \%$ of lymphocytes in milk secreted by diseased udder quarters (SCC $>100 \times 10^{3}$ cells $/ \mathrm{ml}$ ) were clearly lower than those in healthy quarters. Similar observations were described before
(Rivas et al. 2001; Merle et al. 2007; Koess \& Hamann, 2008).

In udder quarters classified as normal secreting (SCC $\leqslant 100 \times 10^{3}$ cells $/ \mathrm{ml}$ ) PMN proportions ranged from 0 to $63 \%$. Our data show that PMN, particularly in milk samples with SCC values $\leqslant 6.25 \times 10^{3}$ cells $/ \mathrm{ml}$, were rare (mean PMN proportion: $10 \%)$. At a SCC level of $(>6 \cdot 25$ to $\leqslant 25)$ $\times 10^{3}$ cells $/ \mathrm{ml}$ the mean proportion of PMN of $14 \%$ was also low. Comparable data for such low SCC values are not available from the literature. Only a mean $\mathrm{PMN}$ proportion of $30 \%$ in udder quarters with SCC of $(0-50) \times 10^{3}$ cells $/ \mathrm{ml}$ was reported previously (Koess \& Hamann, 2008). However, because of an increased transfer of PMN from blood into the mammary gland at the beginning of an inflammation (Kehrli \& Shuster, 1994; Paape et al. 2002; Paape et al. 2003), a high percentage of $\mathrm{PMN}$ in milk is an important indicator of inflammatory reactions (Pillai et al. 2001; Paape et al. 2002). PMN have been reported previously as the predominant cell population in secretions of diseased mammary glands (Paape et al. 1979; Kehrli \& Shuster, 1994). We made the unexpected observation that in milk of udder quarters classified as normal secreting PMN dominated already at SCC $\geqslant 43 \times 10^{3}$ cells $/ \mathrm{ml}$. This finding suggested that inflammatory processes appear already in a SCC range that is clearly below the cut-off value of $100 \times 10^{3}$ cells $/ \mathrm{ml}$. Factors that might have triggered the elevated proportion of PMN might be manifold. A dairy cow is under constant pressure from udder pathogenic microorganisms in the environment. The elevated PMN proportion could be evidence for the initial phase of an inflammation. In this regard it is also possible that PMN are able to defend against pathogens successfully and prevent mastitis. However, although we could not isolate any pathogens in such quarters they might be not healthy anyhow. Negative bacteriological results could depend on intermittent pathogen shedding (Sears et al. 1990), presence of antimicrobials or other inhibitors in milk (Reiter, 1978). At the time of examination pathogens could also be ingested by phagocytes or survive intracellularly in the host (Newbould \& Neave, 1965; Hill et al. 1978). Shedding of too low amounts of pathogens or ceased growth may be further reasons for negative bacteriological results (Sears et al. 1990).

The interdependence of infections, inflammatory processes, and immune responses in individual udder quarters is discussed controversially in the literature. Some authors suggested that individual udder quarters within a cow can be influenced by infections of neighbouring quarters (Merle et al. 2007) whereas others did not find any evidence for an interdependence of udder quarters (Wever \& Emanuelson, 1989) because they did not find DCC to be affected by the bacteriological status of adjacent quarters. Our data indicated no immunological interdepencence between the four udder quarters at low and high SCC levels. In the three udder quarters of three different cows with SCC of $(43-45) \times 10^{3}$ cells $/ \mathrm{ml}$ in foremilk samples, elevated PMN proportions between 54 and $63 \%$ were determined. In the remaining nine quarters of these cows clearly lower SCC 
values of $(4-19) \times 10^{3} \mathrm{cells} / \mathrm{ml}$, lower PMN proportions of $6-18 \%$, and no bacterial infection were detected. Furthermore, no interactions between the quarters were observed in the six cows of the control group with high SCC values $>100 \times 10^{3}$ cell $\mathrm{s} / \mathrm{ml}$ and PMN proportions of $65-92 \%$ in one udder quarter. In these animals SCC $<100 \times 10^{3}$ cells/ $\mathrm{ml}$ and PMN proportions of $4-39 \%$, respectively, were detected in the other three quarters.

Another factor that might have triggered the elevated percentage of PMN is stress (Davis et al. 2008). Although we did not measure parameters related to stress, such as corticosterone in plasma, the influence of stress in our study might be minimal because the animals analysed were kept under optimal conditions and according to national guidelines. No obvious symptoms of stress (i.e. kicking during pre-milking preparation of the udder or during taking the quarter foremilk samples) was observed.

The antidromic trend of lymphocyte and PMN percentages at increasing SCC is caused by the composition of milk leucocytes. Since they consist primarily of lymphocytes, macrophages and PMN (Sordillo \& Nickerson, 1988), the increase of the percentage of one cell population implies the decrease of at least one of the other cell populations. However, our statistical analysis indicated a significant impact of the farms on percentages of both macrophages and lymphocytes. This impact might be due to a nonrandomized selection of cows within the farms and different numbers of cows selected per farm. While cows with healthy mammary glands were predominantly selected from farms A, B and D, samples from cows with diseased quarters were predominantly collected from farm C.

Besides PMN, macrophages also possess phagocytic functions. Milk samples with extremely low SCC values of $\leqslant 6 \cdot 25 \times 10^{3} \mathrm{cells} / \mathrm{ml}$ showed a mean proportion of $32 \%$ of macrophages. In the SCC range of $(>6 \cdot 25$ to $\leqslant 25) \times$ $10^{3}$ cells $/ \mathrm{ml}$ the mean macrophage proportion was $38 \%$. In the literature a mean value of $43 \%$ of macrophages was reported for the SCC range of $(0-50) \times 10^{3}$ cells $/ \mathrm{ml}$ (Koess \& Hamann, 2008). In the case of diseased udder quarters (SCC $>100 \times 10^{3}$ cells $/ \mathrm{ml}$ ) we measured macrophage proportions of $9-28 \%$. These results lay also within a wide range of $4-48 \%$ as mentioned in other studies (Rivas et al. 2001; Merle et al. 2007; Koess \& Hamann, 2008). While we found that macrophages were the second dominant cell population in almost all samples tested in relationship to lymphocytes and PMN, they had been reported to be the predominant cell population in milk of healthy mammary glands (Lee et al. 1980). This difference might be explainable by different definitions of healthy mammary glands. In our study we focused on the analysis of immune cells in milk with very low SCC values. However, Lee et al. (1980) defined mammary glands as healthy based on negative bacteriological examinations and did not present any SCC values.

Besides leucocytes, epithelial cells can also be found in milk. In the literature (Lee et al. 1980; Koess \& Hamann, 2008) low proportions of epithelial cells of $1-3 \%$, which were similar to our examinations (data not shown), were described. Other researchers reported epithelial cell proportions of $10-19 \%$ (Miller et al. 1991) or even 44\% (Leitner et al. 2000). However, proportions of $\geqslant 10 \%$ should be discussed critically. Miller et al. (1991) analysed milk of primiparous cows during the first $75 \mathrm{~d}$ of lactation, whereas Leitner et al. (2000) measured epithelial cells by flow cytometry based on a non-specific identification procedure.

Variations in the distribution of leucocytes in milk from non-infected mammary glands as shown in other studies, were probably dependent on differences in methods, sampling, investigators (Schröder \& Hamann, 2005), breed (Leitner et al. 2003), stage of lactation (Vangroenweghe et al. 2001; Dosogne et al. 2003) and variable SCC. Contrary to other authors (Schröder \& Hamann, 2005), we did not observe influences of the composition of the sample tubes (glass or plastic) on differences of phagocytic cell percentages (data not shown).

In our study bacteriological examinations revealed udder pathogenic microorganisms in only 2 of the 78 udder quarters analysed ( 2 of the 6 control quarters). Esch. coli, however, was found in a quarter with high SCC of $967 \times 10^{3}$ cells $/ \mathrm{ml}$ (DCC: lymphocytes $6 \%$, PMN $85 \%$, macrophages 9\%), whereas Staph. aureus was detected in a quarter with SCC of $1824 \times 10^{3}$ cells/ml (DCC: lymphocytes 5\%, PMN 86\%, macrophages 9\%). These few bacteriological findings did not allow any assessment. However, other studies (Piccinini et al. 1999) also found PMN to be the dominant cell population in milk of udder quarters infected with major pathogens.

\section{Conclusion}

SCC is an undisputed and well-established criterion for the evaluation of udder health and milk quality. However, in addition to SCC, DCC can be used for a more detailed analysis of udder health status. Analysing DCC of mammary glands classified as normal secreting by SCC $<100 \times 10^{3} \mathrm{cells} / \mathrm{ml}$, inflammatory reactions were already detectable at a SCC level of $\geqslant 43 \times 10^{3}$ cell $\mathrm{s} / \mathrm{ml}$ due to predominating PMN proportions in foremilk samples of the corresponding udder quarters. This is the first study indicating inflammatory reactions in udder quarters with SCC that were clearly below the current threshold of $100 \times 10^{3}$ cells $/ \mathrm{ml}$.

The authors are grateful to U Eskens, T Kinder, A Nesseler, K Risse and $M$ Sander for their excellent technical assistance. We thank the four dairy farms for their excellent cooperation. Furthermore, we thank Jessica Olbrich, Renata Piccinini, Gabriel Leitner and Ariel Luis Rivas for critical reading of the manuscript.

\section{References}

Coles EH 1974 Leukocytes. In: Veterinary Clinical Pathology, 6th Edn, pp. 40-98. Philadelphia PA, USA: W B Saunders Company 
Davis AK, Maney DL \& Maerz JC 2008 The use of leukocyte profiles to measure stress in vertebrates: a review for ecologists. Functional Ecology 22 760-772

Dohoo IR \& Meek AH 1982 Somatic cell counts in bovine milk. Canadian Veterinary Journal 23 119-125

Dosogne H, Vangroenweghe F, Mehrzad J, Massart-Leën AM \& Burvenich C 2003 Differential leukocyte count method for bovine low somatic cell count milk. Journal of Dairy Science $\mathbf{8 6}$ 828-834

DVG (Deutsche Veterinärmedizinische Gesellschaft) 2000 [Guidelines for the collection of milk samples under antiseptic conditions.] Giessen, Germany: German Veterinary Society

DVG (Deutsche Veterinärmedizinische Gesellschaft) 2002 [Guidelines for the control of bovine mastitis as a herd problem.] Giessen, Germany: German Veterinary Society

Harmon RJ 1994 Physiology of mastitis and factors affecting somatic cell counts. Journal of Dairy Science 77 2103-2112

Hill AW, Shears AL \& Hibbitt KG 1978 The elimination of serum-resistant Escherichia coli from experimentally infected single mammary glands of healthy cows. Research in Veterinary Science 85 89-93

IDF, International Dairy Federation 1981 Laboratory methods for use in mastitis work. Document 132. Brussels, Belgium: IDF

Kehrli ME \& Shuster DE 1994 Factors affecting milk somatic cells and their role in health of the bovine mammary gland. Journal of Dairy Science 77 619-627

Koess C \& Hamann J 2008 Detection of mastitis in the bovine mammary gland by flow cytometry at early stages. Journal of Dairy Research $\mathbf{7 5}$ 225-232

Lee CS, FBP Wooding P \& Kemp P 1980 Identification properties and differential counts of cell populations using electron microscopy of dry cows secretions, colostrum and milk from normal cows. Journal of Dairy Research 47 39-50

Leitner G, Shoshani E, Krifucks O, Chaffer M \& Saran A 2000 Milk leucocyte population patterns in bovine udder infection of different aetiology. Journal of Veterinary Medicine. B, Infectious Diseases and Veterinary Public Health 47 581-589

Leitner G, Eligulashvily R, Krifucks O, Perl S \& Saran A 2003 Immune cell differentiation in mammary gland tissues and milk of cows chronically infected with Staphylococcus aureus. Journal of Veterinary Medicine. B, Infectious Diseases and Veterinary Public Health 50 45-52

Littell RC, Henry PR \& Ammerman CB 1998 Statistical analysis of repeated measures data using SAS procedures. Journal of Animal Science $\mathbf{7 6}$ $1216-1231$

Medzhitov R 2007 Recognition of microorganisms and activation of the immune response. Nature 449 819-826

Merle R, Schröder AC \& Hamann J 2007 Cell function in the bovine mammary gland: a preliminary study on interdependence of healthy and infected udder quarters. Journal of Dairy Research 74 174-179

Miller RH, Paape MJ \& Fulton LA 1991 Variation in milk somatic cells of heifers at first calving. Journal of Dairy Science 74 3782-3790

Newbould FHS \& Neave FK 1965 The recovery of small numbers of Staphylococcus aureus infused into the bovine teat cistern. Journal of Dairy Research 32 157-162

Nickerson SC 1989 Immunological aspects of mammary involution. Journal of Dairy Science 72 1665-1678

Olde Riekerink RGM, Barkema HW, Veenstra W, Berg FE, Stryhn H \& Zadoks RN 2007 Somatic cell counts during and between milkings. Journal of Dairy Science 90 3733-3741

Oviedo-Boyso J, Valdez-Alarcón JJ, Cajero-Juárez M, Ochoa-Zarzosa A, López-Meza JE, Bravo-Patiño A \& Baizabal-Aguirre VM 2007 Innate immune response of bovine mammary gland to pathogenic bacteria responsible for mastitis. Journal of Infection 54 399-409
Paape MJ, Wergin WP, Guidry AJ \& Pearson RE 1979 Leukocytes-Second line of defense against invading mastitis pathogens. Journal of Dairy Science 62 135-153

Paape MJ, Mehrzad J, Zhao X, Detilleux J \& Burvenich C 2002 Defense of the bovine mammary gland by polymorphonuclear neutrophil leukocytes. Journal of Mammary Gland Biology and Neoplasia 7 109-121

Paape MJ, Bannerman DD, Zhao X \& Lee J-W 2003 The bovine neutrophil: structure and function in blood and milk. Veterinary Research 34 597-627

Pappenheim A 1912 [Staining of blood cells in clinical dried-blood preparation of hematopoietic tissue according to my method.]. Folia Haematologica: Internationales Magazin für klinische und morphologische Blutforschung 13 337-344

Piccinini R, Bronzo V, Moroni P, Luzzago C \& Zecconi A 1999 Study on the relationship between milk immune factors and Staphylococcus aureus intramammary infections in dairy cows. Journal of Dairy Research $\mathbf{6 6}$ 501-510

Pillai SR, Kunze E, Sordillo LM \& Jayarao BM 2001 Application of differential inflammatory cell count as a tool to monitor udder health. Journal of Dairy Science 84 1413-1420

Reiter B 1978 Review of progress of dairy science-Anti-microbial systems in milk. Journal of Dairy Research 45 131-147

Rivas AL, Quimby FW, Blue J \& Coksaygan O 2001 Longitudinal evaluation of bovine mammary gland health status by somatic cell counting, flow cytometry, and cytology. Journal of Veterinary Diagnostic Investigation 13 399-407

Sarikaya H, Werner-Misof C, Atzkern M \& Bruckmaier RM 2005 Distribution of leucocyte populations, and milk composition, in milk fractions of healthy quarters in dairy cows. Journal of Dairy Research 72 486-492

Sarikaya H \& Bruckmaier RM 2006 Importance of the sampled milk fraction for the prediction of total quarter somatic cell count. Journal of Dairy Science 89 4246-4250

Schröder AC \& Hamann J 2005 The influence of technical factors on differential cell count in milk. Journal of Dairy Research 72 153-158

Schwarz D, Diesterbeck US, Failing K, König S, Brügemann K, Zschöck M, Wolter W \& Czerny C-P 2010 Somatic cell counts and bacteriological status in quarter foremilk samples of cows in Hesse, Germany-A longitudinal study. Journal of Dairy Science 93 5716-5728

Sears PM, Smith BS, English PB, Herer PS \& Gonzalez RN 1990 Shedding pattern of Staphylococcus aureus from bovine intramammary infections. Journal of Dairy Science 73 2785-2789

Sordillo LM \& Nickerson SC 1988 Morphometric changes in the bovine mammary gland during involution and lactogenesis. American Journal of Veterinary Research 49 1112-1120

Sordillo LM, Shafer-Weaver K \& DeRosa D 1997 Immunobiology of the mammary gland. Journal of Dairy Science 80 1851-1865

Targowski SP 1983 Role of immune factors in protection of mammary gland. Journal of Dairy Science 66 1781-1789

Vangroenweghe F, Dosogne H, Mehrzad J \& Burvenich C 2001 Effect of milk sampling techniques on milk composition, bacterial contamination, viability and functions of resident cells in milk. Veterinary Research 32 565-579

Viguier C, Arora S, Gilmartin N, Welbeck K \& O'Kennedy R 2009 Mastitis detection: current trends and future perspectives. Trends in Biotechnology 27 486-493

Wever PU \& Emanuelson U 1989 Effects of systematic influences and intramammary infection on differential and total somatic cell counts in quarter milk samples of dairy cows. Acta Veterinaria Scandinavica 30 465-474 